\title{
Целинная и вторичная степная растительность как основной критерий проектирования агроэкологических каркасов на постцелинном пространстве
}

\section{Virgin and secondary steppe vegetation as the main criterion for agroecological framework projects in the virgin land campaign area}

\author{
Левыкин С. В., Казачков Г. В., Яковлев И. Г. \\ Levykin S. V., Kazachkov G. V., Yakovlev I. G. \\ Институт степи УрО РАН, г. Оренбург, Россия. E-mail: stepevedy@yandex.ru \\ Institute of Steppe of the Urals Branch of RAS, Orenburg, Russia
}

\begin{abstract}
Peферат. Раскрывается значение сохранившейся целинной степной растительности как семенников и обширных вторичных массивов степной растительности, как ядер агроэкологического каркаса постцелинного пространства. На основе многолетних полевых исследований выделено несколько разновидностей таковых, в качестве примеров приведены наиболее репрезентативные ядра агроэкологического каркаса для староосвоенного северо-запада и постцелинного Предуралья в пределах Оренбургской области.
\end{abstract}

Ключевые слова. Бугульминско-Белебеевская возвышенность, постцелинное пространство, Предуралье, экологический каркас, ядро экологического каркаса.

Summary. The significance of extant steppe vegetation as seed source and of vast secondary steppe plots as cores for the agroecological framework of the virgin land campaign area is revealed. Several options of such ones are distinguished based on long-term field studies. The most representative cores of agroecological framework in old-developed north-west and in the Cis-Ural region undergone virgin land campaign both within Orenburgskaya oblast are given as examples.

Key words. Bugulminsko-Belebeevskaya upland, Cis-Ural region, ecological framework, ecological framework core, virgin land campaign area.

Построение экологических каркасов продолжает оставаться актуальным направлением сохранения ландшатфно-биологического разнообразия степей. Специфика аграрного освоения староосвоенных степных регионов диктует проектирование ООПТ в качестве ядер каркаса, а в качестве коридоров как правило, любые вытянутые природные участки: балки, водотоки, лесополосы.

Считаем, что такой принцип хотя и обусловлен объективной реальностью, но не может учесть современную природоохранную специфику степей (Левыкин, Казачков, 2012).

В выделенном нами постцелинном пространстве пока имеется возможность параллельно с построением репрезентативной сети ООПТ построить и экологический каркас соответствующий как исходной ландшафтно-типологической структуре, так и природоохранной специфике степей (Чибилёв и др., 2014; Чибилёв, 2016; Левыкин и др., 2018). Здесь ещё сохраняется возможность использовать в качестве ядер обширные целинные и вторичные степные экосистемы, определяемые нами в основном по геоботаническим критериям: наличие целинной либо вторичной степной растительности и охраняемых видов. Здесь же пока сохраняется возможность построения экологически сбалансированного аграрного землепользования с переходом от экстенсивного земледелия и лесополос к приоритету природных и полуприродных управляемых травяных экосистем в качестве кормовой базы животноводства. На основании уникальной совместимости природоохранного и хозяйственного значения степных фитоценозов экологический каркас постцелинного пространства рассматривается нами как агроэкологический. 
На основе собственных исследований, проведённых на постцелинном пространстве Заволжско-Уральского степного региона (Левыкин, Казачков, 2013), нами выделены основные центры существования и самовосстановления степных фитоценозов, которые предлагаем использовать в качестве ядер каркаса, соединённых не столько интразональными полосами и лесополосами, сколько полосами степной растительности. На этом основании предлагаем следующее определение агроэкологического каркаса постцелинного пространства, предполагающего управление степными фитоценозами при помощи природоподобных технологий.

Агроэкологический каркас постцелинного пространства - способ территориальной организации сохранения ландшафтно-биологического разнообразия степей, отвечающий их исходной ландшафтно-типологической структуре и способствующий эффективной реализации потенциала самореабилитации степей в агроландшафтном обороте.

Фундаментальной основой выделения ядер каркаса всё-таки является геоботанический подход: констатация фактического наличия и состояния степной растительности, целинной либо близкой к таковой вторичной. Однако акцент делается не столько на фиторазнообразие, сколько на запас или ресурс титульных степных фитодоминантов, прежде всего ковылей (Stipa spp), который оценивается прежде всего по площади произрастания и генеративному потенциалу.

Нами разработаны фундаментальные подходы к дифференциации потенциальных ядер агроэкологического каркаса постцелинного пространства. Целинной растительности на больших площадях практически не сохранилось, но существует достаточно разветвлённая сеть самовосстановленных участков, которые находятся в динамичном сопряжении с окружающими агроландшафтами. Как правило, крупные заросли вторичной степной растительности формируются в сопряжении или вокруг семенников, оказывающихся в ядрах и определяющих сроки и конечный успех самовосстановительных процессов. Мы дифференцировали такие ядра по соотношению площадей семенников к общей площади участка, по динамике границ семенников и динамике внешних границ участка. Для схематического отображения дифференциации использована методика картоидов (Родоман, 2007). Нами выделены следующие типы ядер. Эксплозивные с участками семенников внутри ядра, среди которых различаем: эксплозивное экспансивное с расширяющимися внешними границами; эксплозивное лимитированное со стабильными внешними границами; эксплозивное ретирадное со сжатием внешних границ. Имплозивные с участками залежей внутри ядра представляющего собой семенник, среди которых различаем: имплозивное экспансивное с расширяющимися внешними границами, имплозивное лимитированное со стабильными внешними границами, имплозивное ретирадное со сжатием внешних границ. Прессурные сплошные семенники, среди которых различаем: прессурное осциллярное с колебанием внешних границах; прессурное ретирадное со сжатием внешних границ; прессурное стагнирующее - с постоянными внешними границами и фитоценозами пониженной генеративной активности, как правило, это ООПТ.

Для устойчивого функционирования и развития постцелинного пространства ядра его экологического каркаса должны быть связаны между собой экологическими коридорами, прежде всего для осуществления миграций и генетического обмена. Роль коридоров могут выполнять при условии соблюдения охранного статуса водоохранные зоны малых рек. В качестве агроэкологической альтернативы лесополосам должна быть создана сеть степеполос вокруг полей, которая примет на себя существенную часть функции экологических коридоров в каркасе и семенников в управляемом агроландшафте.

На текущий момент основной мотивацией проектирования агроэкологического каркаса постцелинного пространства с целью отвести степь от черты невозврата является нравственно-этический долг. В перспективе вполне возможны и экономические мотивации в связи с признанием степей важным накопителем углерода и возможностями использования пространства агроэкологических каркасов для полувольного содержания степных копытных (лошадь, аркал, бизон и т. д.).

В настоящее время нами проводится проектирование степного агроэкологического каркаса для постцелинного пространства в пределах Оренбургской и Саратовской областей. Важное значение имеют т.н. приграничные выступы: Алгайский в Саратовской области, Троицкий, Акбулакский и Айтуарский в Оренбургской области. В Троицком проектируется биологический заказник, включающий уни- 
кальную меловую флору, эталоны дерновинно-злаковых степей и массивы вторичных степей. В Айтуарском находится участок ГПЗ «Оренбургский» Айтуарская степь площадью 6,7 тыс. га, где представлены эталоны низкогорных степей Южного Урала. Кроме названных выступов в качестве примера приведём несколько проектируемых ядер для староосвоенного северо-запада Оренбургской области и для постцелинного пространства Оренбургского Предуралья.

Лесостепное ядро является комплексным, связанным с восстановленной усадьбой С. Т. Аксакова, что позволяет ставить вопрос о создании историко-природного комплекса «Лесостепь, воспетая С. Т. Аксаковым» или «Аксаковская лесостепь». Территориальной основой лесостепного ядра являются две параллельные гряды с ранее распаханными грядоосевыми плакорами на вершинах и сохранившейся разнотравно-злаковой степной растительностью на склонах: гор Кудрявая и Челяевская, неоднократно упомянутые в произведениях С. Т. Аксакова и представляющие собой по сути полные степные катены юга Бугульминско-Белебеевской возвышенности. Это ядро площадью порядка 1500 га является имплозивным лимитированным, где протекает частичное самовосстановление распаханных грядоосевых плакоров и требуется экологическая реставрация. На грядоосевых плакорах и более пологих склонах представлены богаторазнотравно-перистоковыльная ассоциации (Salvia nutans L. + Stipa pennata L.). Особо выделяются перистоковыльно-клубничные ассоциации (Stipa pennata L. + Fragaria viridis (Duch) Weston). Островные леса, в т. ч. на плакорах, представлены кленовником ландышевым (Acer platanoides L. - Convallaria majalis L.), дубравами с лещиной, бересклетом (Quercus robur L. - Corylus avellane L. + Euonimus verrucose Scop.).

Следуя принципу каркасности и комплексности, также в качестве историко-природных ядер рассматриваем ценные природоохранные и историко-культурные объекты на историческом маршруте регулярных переездов семьи Аксаковых из усадьбы Аксаково в г. Уфе. Например, горы Луговская и Коровинская, расположенные в 20-25 км восточнее с. Аксаково. Ядро - гора Луговская площадью 160 га - расположено у слияния рек Мал. Мочегай и Узелинка, вершина представляет собой грядоосевой плакор площадью 37 га с восстановленной разнотравно-злаковой растительностью. Доминируют ковыль перистый (Stipa pennata L.), клубника луговая (Fragaria viridis (Duch) Weston), шалфей поникающий (Salvia nutans L.), ярко выраженная мозаичность травостоя. Склоны горы покрыты ксерофитно-солонцоватой растительностью грудницево-овсецовой ассоциации (Crinitaria linosyris (L.) Less. + Helictotrichon pubescens (Huds.) Pilg.). Единично имеется самосев сосны обыкновенной (Pinus silvestris L.). Ядро - гора Коровинская площадью 210 га - расположено в междуречье рек Улькин и Чишмабаш у села Коровино, вершина также представляет собой грядоосевой плакор площадью 50 га с восстановленной богаторазнотравно-ковыльной растительностью, где доминируют ковыль перистый (Stipa pennata L.), шалфей поникающий (Salvia nutans L.), степная клубника (Fragaria viridis (Duch) Weston). Ha этом грядоосевом плакоре отмечен редкий для Оренбургской области ковыль Коржинского (Stipa korshinskyi Roshev.).

В Оренбургском Предуралье выделяется несколько ядер, из которых в данной работе отметим Орловское ядро (по названию расформированного спецучастка «Орловский»). Это ядро общей площадью порядка 60 тыс. га относим к прессурным ретирадным, в его центре находится участок ГПЗ «Оренбургский» «Предуральская степь», созданный для реинтродукции лошади Пржевальского (16, 5 тыс. га), научный стационар Института степи «Оренбургская Тарпания» (35 га), а также крупные массивы галофитных разновидностей степей Предуралья, залежных земель в различных стадиях самовосстановления. Начиная с 2018 г. активизировалось земледельческое освоение залежей, в основном по северной периферии ядра. Это ядро в наибольшей степени соответствует исходной ландшафтной структуре Оренбургского Предуралья, площадь полностью восстановленной разнотравно-красноковыльной (Salvia stepposa Shost. + Astragalus spp. + Stipa zalesskii Wilensky) и разнотравно-лессингоковыльной (Salvia stepposa Shost. + Astragalus spp. + Stipa lessingiana Trin. et Rupr.) растительности на степных плакоров оценивается нами в 9-10 тыс. га.

Несколько восточнее Орловского ядра выделяем сопоставимое по площади Буртинско-Воздвиженское ядро с более выраженным холмистым, грядово-холмистым и грядовым рельефом. Разнообразие мест обитания, включая различные варианты плакоров, обусловило наличие практически всех видов перистых и остистых ковылей, включая ковыль восточный (Stipa orientalis Trin.), свойственных не 
только Оренбургскому Предуралью, но и Оренбургской области в целом. Возможно, поэтому именно здесь нами на пологих склонах каменистых увалов отмечена особая форма ковыля, по габитусу промежуточная между ковылём Лессинга (Stipa lessingiana) и ковылём восточным (Stipa orientalis). Рискнём предположить, что это может оказаться особым предуральским петрофитным подвидом ковыля Лессинга по аналогии с «новороссийским» эндемиком - особым каменистым подвидом Stipa lessingiana brauneri Pacz, выделенным для Крыма и Северо-Западного Кавказа (Клоков, Осыпчук, 1976). Для определения таксономического статуса найденной формы ковыля требуются специализированные исследования.

На текущий год запланировано завершение исследований по проектированию агроэкологического каркаса постцелинного пространства в рамках модельной Оренбургской области и сопредельной с ней Саратовской области.

Благодарности. Работа выполнена по проекту РНФ № 17-17-01091 «Стратегия пространственного развития степных и постцелинных регионов Европейской России на основе каркасного территориального планирования и развития непрерывных экологических сетей».

\section{ЛИТЕРАТУРА}

Клоков М. В., Осыпчук В. В. Ковыли Украины //Новости систематики высших и низших растений, 1975. Киев, 1976. - С. 7-92.

Левыкин С. В., Казачков Г. В. Природоохранная специфика степей для земельной политики // Проблемы геоэкологии и степеведения. Т. 3. / Под ред. А .А. Чибилёва и О. Г. Грошевой. - Екатеринбург: УрО РАН, 2012. - С. 91-95.

Левыкин С.В., Казачков Г. В. Stipa lessingiana в самореабилитации зональных степных ландшафтов и возможности Красных Книг по их защите // Флора и растительность Центрального Черноземья - 2013: Материалы межрегиональной науч. конф. (г. Курск, 6 апреля 2013 г.). - Курск, 2013. - С. 112-115.

Левыкин С. В., Казачков Г. В., Нурушев М. Ж. Ландшафтная матрица ковыльных степей постцелинного пространства // Степи Северной Евразии: материалы VIII междунар. симпозиума /под науч. ред. акад. РАН А. А. Чибилёва. - Оренбург: ИС УрО РАН, 2018. - С. 561-564.

Родоман Б. Б. География, районирование, картоиды: Сборник трудов. - Смоленск: Ойкумена, 2007. - 368 с.

Чибилёв $\boldsymbol{A}$. $\boldsymbol{A}$. Степная Евразия: региональный обзор природного разнообразия. - М.; Оренбург: Институт степи УрО РАН, РГО, 2016. - 324 с.

Чибилёв А. А., Вельмовский П. В., Левыкин С. В., Чибилёв А. А. мл. О перспективах организации новой ООПТ в Оренбургском Предуралье // Оренбургский заповедник: значение для сохранения степных экосистем России и перспективы развития. - Оренбург, 2014. - С. 160-165. 